\title{
Studies on the Combined Water in Paste for Lead Storage Batteries*
}

\author{
Shin-ichi Ikari**
}

Works have been done by many workers to determin the chemical formulas for $\mathrm{PbO}-\mathrm{PbSO}_{4}$ compounds. In regard to the combined water of paste, J.J. Lander ${ }^{1}$ reported the formation of monohydrate of tribasic lead sulfate in samples formed by the wet method, and T. Takagaki ${ }^{2}$ studied the formation of the same salt in the $\mathrm{PbO}-\mathrm{H}_{2} \mathrm{SO}_{4}$ paste of storage batteries. But the temperature of decomposition of this salt was different from that of J.J., Lander.

Author and coworkers studied, by thermal and $\mathrm{X}$-ray analysis, the composition of hydrous compound in the $\mathrm{PbO}$ (tetragonal) $-\mathrm{H}_{2} \mathrm{SO}_{4}$ paste, which was dried by steaming or air heating, and the nature of the combined water. This report is concerned with the result of thermoanalysis. The combined water was measured by the weight change of paste on heating by means of a silica spiral thermobalance in a vaccum of $10^{-2}$ to $10^{-3} \mathrm{mmHg}$.

The sample for analysis was prepared as follows :

1) by mixing $\mathrm{PbO}$ (tetragonal) with different activities ${ }^{3)}$ and dil. $\mathrm{H}_{2} \mathrm{SO}_{4}$ and drying the mixtures perfectly by heating at $70-80^{\circ} \mathrm{C}$.

2) by mixing $\mathrm{PbO}$ and dil $\mathrm{H}_{2} \mathrm{SO}_{4}$ with the aid of the paste diagram of $\mathrm{PbO}-\mathrm{H}_{2} \mathrm{SO}_{4}$ systems, and drying the mixtures by air heating at $70-80^{\circ} \mathrm{C}$ or by steam heating at $100^{\circ} \mathrm{C}$.

3) by standing the pasted plate containing $0-49 \%$ of $\mathrm{PbSO}_{4}$ and the sample formed by the wet method in wet $\mathrm{CO}_{2}, \mathrm{O}_{2}$, and air at $1 \mathrm{~atm}$.

4) by the wet method used by J.J. Lander., by boiling and standing at low temperature water suspensions of $\mathrm{PbO}$ and $\mathrm{PbSO}_{4}$ (or $\mathrm{H}_{2} \mathrm{SO}_{4}$ ) in the proper ratio. These are represented by the formulas : $\mathrm{PbSO}_{4} \cdot \mathrm{PbO}, \mathrm{PbSO}_{4} \cdot 3 \mathrm{PbO}, \mathrm{PbSO}_{4} \cdot 4 \mathrm{PbO}$ and $\mathrm{PbSO}_{4} \cdot 2 \mathrm{PbCO}_{3} \cdot \mathrm{PbO}$.

The results obtained are summarized as follows :

1) There are two combined water in the paste dried by heating at $70-80^{\circ} \mathrm{C}$, which are decomposed above about $90-120^{\circ} \mathrm{C}$ and $170^{\circ} \mathrm{C}$.

2) The combined water decomposed on heating at $170^{\circ} \mathrm{C}$ seems to relate to the monohydrate of tribasic lead sulfate $\left(\mathrm{PbSO}_{4} \cdot 3 \mathrm{PbO} \cdot \mathrm{H}_{2} \mathrm{O}\right)$, and the maximum water loss does not occur at $31 \%$ of $\mathrm{PbSO}_{4}$ but at about $25 \%$. It seems that this divergence from theoretical value is due to the particle size of $\mathrm{PbO}$, but the water quantites are affected by the degree of catalystic activity of $\mathrm{PbO}$.

3) When in air, there are the combined waters also which seem to depend on the basic lead carbonate decomposed at about $170^{\circ} \mathrm{C}$. This basic lead carbonate releases $\mathrm{CO}_{2}$ at about $225^{\circ} \mathrm{C}$ and this combined water does not exist in the paste containing about $30 \%$ of $\mathrm{PbSO}_{4}$, and it is considered that such combined water depends on the basic lead corbonate formed by reaction $\mathrm{CO}_{2}$ and $\mathrm{PbO}$ which is remained in the paste as in (Fig. 1).

4) It is certain that the monohydrate of tribasic lead sulfate loses rather easily the combined water through action of the $\mathrm{CO}_{2}$ in the air and anhydrous rbonate is formed.

The paste formed by steaming differs from that formed by heating the following points :

1) The combined water due to decomposition of the basic lead sulfate at $170^{\circ} \mathrm{C}$ does not exist in the paste containing $0-15 \%$ of $\mathrm{PbSO}_{4}$. But crystals which seem to be basic lead sulfate are observed by optical microscope. It seems that this salt may be on anhydrous compound as in (Fig. 2).

2) There is the combined water in the paste which is decomposed at about $210^{\circ} \mathrm{C}$ besides that

* Studies on the Paste for Lead Storage Batteries (Part 1)

** Kobe-Electric Co. Ltd.

The original written in Japanese can be seen in J. Electrochem. Soc. Japan 27, 385 (1959). 


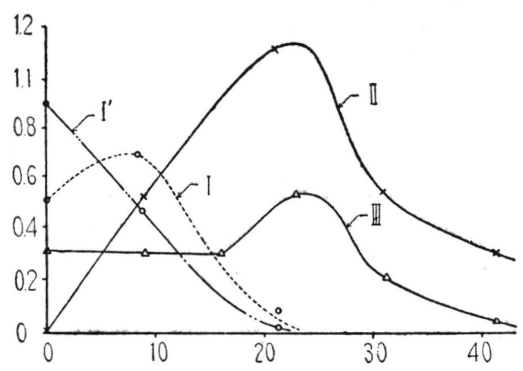

Curve I; the paste was settled in $\mathrm{CO}_{2}$ at room temp.

Curve II ; the paste was settled in $\mathrm{O}_{2}$ at room temp.

Curve III; the paste was dried in air at room temp.

Curve I', was recalculated from curve I under the case as these pastes involved the same percent $\mathrm{PbCO}_{3}$.

Fig. 1 Combined water which was decomposed at about $170^{\circ} \mathrm{C}$ in the paste dried by heating.

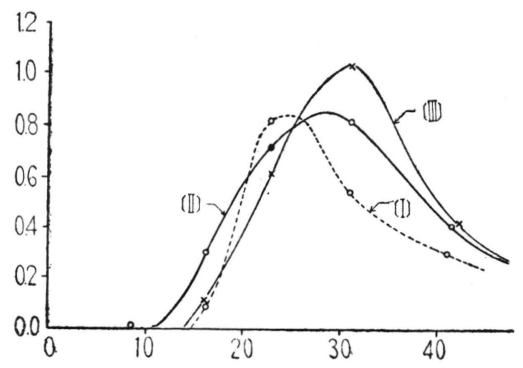

Curve I and II; the combined water decomposed at about $17^{\circ} \mathrm{C}$ and $210^{\circ} \mathrm{C}$ respectively.

Curve III; the combined water decomposed at about $210^{\circ} \mathrm{C}$ in the samples prepared by the wet method.

Fig. 2 Combined water in the pastes dried by steaming.

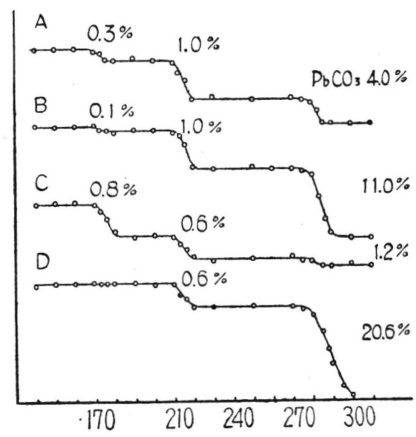

A; The sample was prepared by the wet method.

B; Sample A was settled in $\mathrm{CO}_{2}$.

C; The paste was dried by steaming.

D; Sample C was settled in $\mathrm{CO}_{2}$.

Fig. 3 Thermoanalysis curves.

which decomposes at about $170^{\circ} \mathrm{C}$. Also this combined water seems to be related to the monohydrate of tribasic lead sulfate; and the maximum content is seen in the paste containing about $31 \%$ of $\mathrm{PbSO}_{4}$. 3) The combined water decomposed at $170^{\circ} \mathrm{C}$ is released by $\mathrm{CO}_{2}$ in the same way as the paste dried by heating, but water decomposed at $210^{\circ} \mathrm{C}$ can not be observed in (Fig. 3). 
It was supposed, that difference in decomposition temperature may be due to the degree of crystallization of the basic salt.

\section{Literature :}

(1) J.J. Lander, Trans. Electrochem. Soc. 95, 174 (1949).

(2) T. Takagaki, Electrochem. Soc. of Japan 23, 173, 232, 399, 449, 567 (1955).
ibid.
25, 492 (1957).
ibid.
26, 278 (1958).

(3) G.L. Clark, J. Amer. Chem. Soc. 63, 1302 (1941). 